\title{
PENERAPAN PROBLEM BASED LEARNING UNTUK MENINGKATKAN KETERAMPILAN ARGUMENTASI LISAN SISWA KELAS XI PADA PEMBELAJARAN BIOLOGI
}

\author{
Latifatul Faizah \\ Program Studi S-1 Pendidikan Biologi Fakultas Keguruan dan Ilmu Pendidikan \\ Universitas Sebelas Maret Surakarta, Jl. Ir. Sutami No. 36 Ketingan Surakarta \\ Emal: faizahlatifatul@gmail.com \\ Riezky Maya Probosari \\ Program Studi S-1 Pendidikan Biologi Fakultas Keguruan dan Ilmu Pendidikan \\ Universitas Sebelas Maret, Surakarta Jl. Ir. Sutami No. 36 Ketingan Surakarta \\ Email: riezkymaya@ fkip.uns.ac.id

\section{Puguh Karyanto} \\ Program Studi S-1 Pendidikan Biologi Fakultas Keguruan dan Ilmu Pendidikan \\ Universitas Sebelas Maret Surakarta, Jl. Ir. Sutami No. 36 Ketingan Surakarta \\ Email: karyarina@yahoo.com
}

\begin{abstract}
Abstrak
Penelitian bertujuan untuk meningkatkan keterampilan argumentasi lisan siswa. Jenis penelitian ini adalah penelitian tindakan kelas (classroom action research) dengan penerapan Problem Based Learning yang meliputi lima tahapan pembelajaran, yaitu problem encounter, problem analysis and learning issues, discovery and reporting, solution presentation and reflection, dan overview integration and evaluation. Subjek penelitian adalah siswa kelas XI MIPA di salah satu SMA di Surakarta yang berjumlah 37 siswa (19 laki-laki dan 18 perempuan). Teknik pengumpulan data dengan observasi, wawancara, dan dokumentasi proses pembelajaran biologi. Teknik analisis data menggunakan teknik analisis deskriptif kualitatif dan prosedur penelitian tindakan kelas mengikuti model penelitian dari Coghlan \& Brannick. Penilaian keterampilan argumentasi lisan siswa mengacu pada McNeill \& Krajcik terdiri dari claim, evidence, dan reasoning. Hasil penelitian menunjukkan adanya peningkatan keterampilan argumentasi lisan siswa mengalami peningkatan dari level rendah ke level sedang dengan rata-rata skor keterampilan argumentasi lisan siswa pada prasiklus 0,19 , siklus I 1,43, dan siklus II 3,49, serta rata-rata skor 5 pada siklus III. Berdasarkan hasil penelitian disimpulkan bahwa ada peningkatan keterampilan argumentasi lisan siswa melalui Problem Based Learning di kelas XI MIPA pada pembelajaran biologi.
\end{abstract}

Kata kunci: keterampilan argumentasi lisan, pembelajaran biologi, penelitian tindakan kelas, problem based learning.

\footnotetext{
Abstract

The research aim is to improve skill argumentation of students orally. This research is classroom action research with the application of the problem based learning which includes five steps of learning (the problem encounter, the problem analysis and learning issues, discovery and reporting, solution presentation and
} 
reflection, and the overview of integration and evaluation). The subject of study was students class XI MIPA of senior high school in Surakarta which consisted of 37 students with 19 men and 18 women. Data collected by observation techniques, interview, and documentation of biology teaching process. The data analyzed by using descriptive qualitative analysis and the research procedure applied Coghlan \& Brannick model. Skills assessment of oral argument of the students referred to McNeill \& Krajcik which consisted of claim, evidence, and reasoning. The research results show the skill of oral argument of the students has increased from a lower level to the moderate levels (0,19 of pre cycle, 1,43 of first cycle, and 3,49 of the second cycle with the average score that is 5 of the third cycle. It can be concluded that there is an increase of skills of oral argument of the students in learning biology which applied problem based learning.

Keyword: Skills assessment of oral argument of the students, biology learning, classroom action research, problem based learning.

\section{PENDAHULUAN}

Keterampilan argumentasi adalah salah satu keterampilan yang harus dikembangkan atau dilatihkan kepada siswa dalam kegiatan pembelajaran. Menurut Cross et al. (2008) keterampilan argumentasi dalam pendidikan sains merupakan suatu hal yang penting, karena keterampilan argumentasi dapat meningkatkan pemahaman siswa mengenai konsep serta memperluas pengetahuannya melalui cara memperoleh ide-ide yang baru. Syaifudin \& Pratama (2013) mengungkapkan bahwa melalui argumentasi seseorang dapat menujukkan pernyataan-pernyataan (teori-teori) yang dikemukakan benar atau tidak dengan mengacu pada fakta atau bukti-bukti yang ditujukan.

Menurut McNeill \& Krajcik (2009) sebuah argumentasi ilmiah terdiri dari tiga aspek utama, yaitu claim, evidence, dan reasoning. Claim merupakan pernyataan atau jawaban atas pertanyaan atau permasalahan, evidence merupakan informasi atau data yang mendukung claim. Bukti (evidence) dapat berupa data yang dikumpulkan siswa atau dari sumber lain seperti informasi dari buku atau internet. Reasoning merupakan sebuah pembenaran atau penjelasan yang menunjukkan mengapa data atau informasi dapat digunakan sebagai bukti (evidence) yang mendukung pernyataan (claim). Penjelasan (reasoning) harus mampu menghubungkan antara bukti (evidence) dengan pernyataan (claim), yang mana di dalamnya mencakup prinsip-prinsip ilmiah.

Berdasarkan hasil observasi di salah satu SMA swasta di Surakarta diketahui bahwa keterampilan argumentasi siswa masih rendah. Hal ini ditunjukkan dengan hanya 
7 orang siswa dari 37 siswa dalam kelas yang dapat membuat pernyataan (claim). Pernyataan yang dibuat masih termasuk kategori rendah dengan skor 1 dan siswa belum mampu mengungkapkan evidence maupun reasoning atas pernyataan (claim) yang disampaikan. Rendahnya keterampilan argumentasi siswa ini terjadi karena selama kegiatan pembelajaran siswa cenderung terpaku pada buku paket atau LKS saja. Di samping itu, guru juga belum mampu memfasilitasi siswa dalam kegiatan pembelajaran untuk menyampaikan argumentasi secara lisan. Diskusi yang sebetulnya dapat meningkatkan keterampilan argumentasi secara lisan, hanya dilaksanakan pada waktu tertentu saja misalnya pada saat ada kegiatan praktikum. Oleh sebab itu, diperlukan adanya penerapan pembelajaran yang dapat memfasilitasi siswa untuk berlatih menyampaikan argumentasi.

Salah satu alternatif yang dapat digunakan adalah melaksanakan kegiatan pembelajaran yang menyediakan kesempatan kepada siswa untuk melakukan kegiatan diskusi seperti model pembelajaran berdasarkan pada masalah. Hal ini sesuai dengan pendapat Kultuca et al. (2014) bahwa untuk mengembangkan keterampilan argumentasi dalam pembelajaran diperlukan adanya kegiatan diskusi yang dilakukan oleh siswa. Pembelajaran berdasarkan masalah adalah kegiatan pembelajaran yang menggunakan model pembelajaran PBL (Problem Based Learning). PBL adalah salah satu model pembelajaran aktif dengan pendekatan berpusat pada siswa (student centered) yang menggunakan permasalahan (masalah kompleks yang nyata atau simulasi) sebagai titik awal untuk proses pembelajaran. Pembelajaran ini tidak hanya sebatas proses pemecahan masalah, tetapi sebuah pembelajaran konstruktivisme yang mana permasalahan nyata dihubungkan dengan rancangan lingkungan belajar yang mencakup kegiatan-kegiatan penyelidikan, belajar mandiri, penambahan informasi, dialog, dan penggabungan pemecahan masalah yang saling berkaitan satu sama lain. Kegiatan pembelajaran dengan model PBL melalui lima tahapan utama, yaitu problem encounter, problem analysis and learning issues, discovery and reporting, solution presentation and reflection, overview integration and evaluation (Tan, 2007).

Penelitian ini bertujuan untuk mengetahui bagaimana peningkatan keterampilan argumentasi lisan siswa XI MIPA dengan adanya penerapan Problem Based Learning (PBL) pada pembelajaran biologi. 


\section{METODOLOGI PENELITIAN}

Penelitian ini dilaksanakan pada salah satu SMA di Surakarta dengan subyek penelitian siswa kelas XI MIPA dengan jumlah siswa sebanyak 37 siswa (19 laki-laki dan 18 perempuan). Penelitian ini adalah penelitian tindakan kelas (classroom action research) yang dilaksanakan selama tiga siklus. Teknik pengumpulan data menggunakan teknik observasi untuk melihat secara langsung pelaksanaan kegiatan pembelajaran, wawancara untuk memperoleh informasi atau tanggapan dari siswa maupun guru mengenai kegiatan pembelajaran yang telah dilaksanakan, dan dokumentasi berupa foto atau video proses pembelajaran saat penelitian dilaksanakan. Teknik analisis data menggunakan teknik analisis deskriptif kualitatif dan prosedur penelitian mengikuti model penelitian tindakan kelas (classroom action research) dari Coghlan \& Brannick (2010).

\section{HASIL PENELITIAN DAN PEMBAHASAN}

Hasil observasi proses pembelajaran biologi pada kelas XI MIPA 3 menunjukkan peningkatan keterampilan argumentasi lisan siswa melalui kegiatan pembelajaran Problem Based Learning. Peningkatan yang terjadi dari prasiklus hingga siklus III dikarenakan pelaksanaan pembelajaran yang menerapkan model pembelajaran Problem Based Learning sehingga mengakomodasi atau memfasilitasi siswa untuk dapat menyampaikan argumentasi secara lisan. Hasil analisis terhadap keterampilan argumentasi lisan siswa yang terdiri dari tiga aspek yaitu claim, evidence, dan reasoning menunjukkan adanya perubahan. Perbandingan skor aspek claim keterampilan argumentasi lisan di setiap siklus disajikan pada gambar 1.

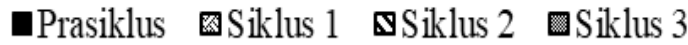

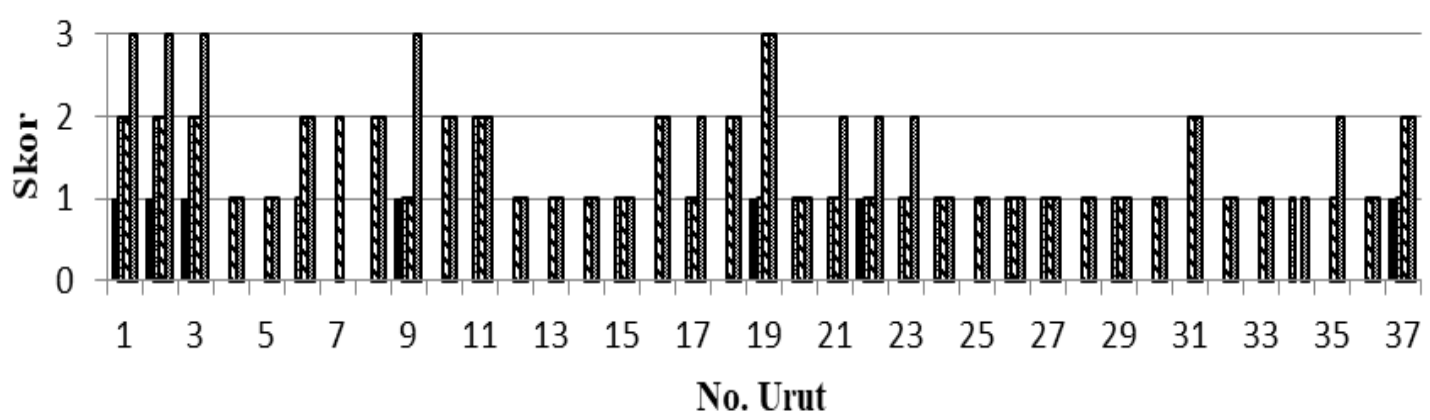

Gambar 1. Skor Aspek Claim Tiap Siklus 
Berdasarkan gambar 1 terlihat bahwa skor aspek claim pada setiap siswa bervariasi. Siswa dengan nomor urut 1, 2, dan 3 mengalami peningkatan dari prasiklus ke siklus III tetapi tidak mengalami perubahan dari siklus I ke siklus II. Hal ini terjadi karena siswa masih tetap menyampaikan claim dalam kategori sedang baik pada siklus I maupun siklus II dan menyampaikan claim dalam kategori tinggi pada siklus III. Kita dapat melihat contoh claim yang disampaikan siswa pada tabel 1.

Tabel 1. Contoh analisa aspek Claim dalam Argumentasi

\begin{tabular}{|c|c|}
\hline $\begin{array}{l}\text { Bagaiamana cara mengatasi dan } \\
\text { sistem peredaran darah manusia? } \\
\quad \text { Claim }\end{array}$ & $\begin{array}{c}\text { gangguan atau penyakit pada } \\
\text { Keterangan }\end{array}$ \\
\hline $\begin{array}{l}\text { 2. Cara mengatasi dan mencegah gangguan/penyakit } \\
\text { pada sistem peredaran darah manusia adalah } \\
\text { menghindari merokok dan perokok karena dapat } \\
\text { mengganggu sistem peredaran darah manusia, } \\
\text { membuat keping darah menghitam dan kelama- } \\
\text { lamaan dapat membuat alat peredaran darah pecah, } \\
\text { dan berujung kematian mendadak. Selain itu, juga } \\
\text { diperlukan menjaga pola makan dan memakan } \\
\text { makanan yang seimbang, serta menghindari makanan } \\
\text { berkolesterol tinggi karena dapat menyumbat sistem } \\
\text { peredaran darah. }\end{array}$ & $\begin{array}{lr}\text { Claim yang disampaikan } \\
\text { termasuk dalam kategori tinggi } \\
\text { karena pernyataan } r \text { yang } \\
\text { disampaikan } & \text { memberikan } \\
\text { jawaban atas } & \text { sebuah } \\
\text { pertanyaan. } & \end{array}$ \\
\hline $\begin{array}{l}\text { 10. Gangguan/penyakit pada sistem peredaran darah } \\
\text { dapat diatasi gdengan menjaga kondisi tubuh dan } \\
\text { makan makanan yang sehat dan bergizi serta tidak } \\
\text { melakukan kegiatan yang membahayakan sistem } \\
\text { peredaran darah seperti merokok. }\end{array}$ & $\begin{array}{l}\text { Claim yang disampaikan } \\
\text { termasuk dalam kategori } \\
\text { sedang karena pernyataan yang } \\
\text { disampaikan merupakan } \\
\text { sebuah kesimpulan }\end{array}$ \\
\hline $\begin{array}{l}\text { 27. Cara untuk menghadapi gangguan/penyakit pada } \\
\text { sistem peredaran darah tindakan pencegahan yang } \\
\text { dapat dilakukan adalah menjaga pola hidup sehat } \\
\text { dengan olahraga dan menghindari rokok. }\end{array}$ & $\begin{array}{l}\text { Claim yang disampaikan } \\
\text { termasuk dalam kaetgori } \\
\text { rendah karena pernyataan yang } \\
\text { disampaikan merupakan } \\
\text { pendapat pribadi. }\end{array}$ \\
\hline
\end{tabular}

Gambar 1 juga menunjukkan bahwa siswa nomor 19 memiliki skor tertinggi aspek claim pada siklus II dan siswa nomor 1, 2, 3, 9, serta 19 memiliki skor tertinggi aspek claim pada siklus III. Pendapat (claim) yang disampaikan oleh siswa nomor 2 (Tabel 1) adalah pernyataan yang termasuk dalam kategori tinggi, yaitu berisi jawaban dari pertanyaan yang disampaikan, seperti halnya pendapat Berland \& McNeill (2010) mengatakan bahwa claim merupakan sebuah pernyataan jawaban atas sebuah pertanyaan. Sedangkan, claim dalam argumentasi yang disampaikan oleh siswa nomor 
10 termasuk dalam kategori sedang dan claim dalam argumentasi yang disampaikan oleh siswa nomor 27 termasuk dalam kategori rendah.

Siswa dengan nomor urut 34 mengalami peningkatan dari prasiklus ke siklus I dan dari siklus II ke siklus III meskipun mengalami penurunan dari siklus I ke II, sedangkan siswa dengan nomor urut 7 mengalami peningkatan mulai dari siklus I ke siklus II tetapi mengalami penurunan skor pada siklus III. Siswa nomor 7 dan 34 sempat mengalami penurunan skor karena mereka tidak hadir dalam kegiatan pembelajaran.

Uraian di atas memaparkan aspek claim siswa pada argumentasi lisan. Perbandingan perolehan skor pada aspek evidence yang disajikan pada gambar 2 .

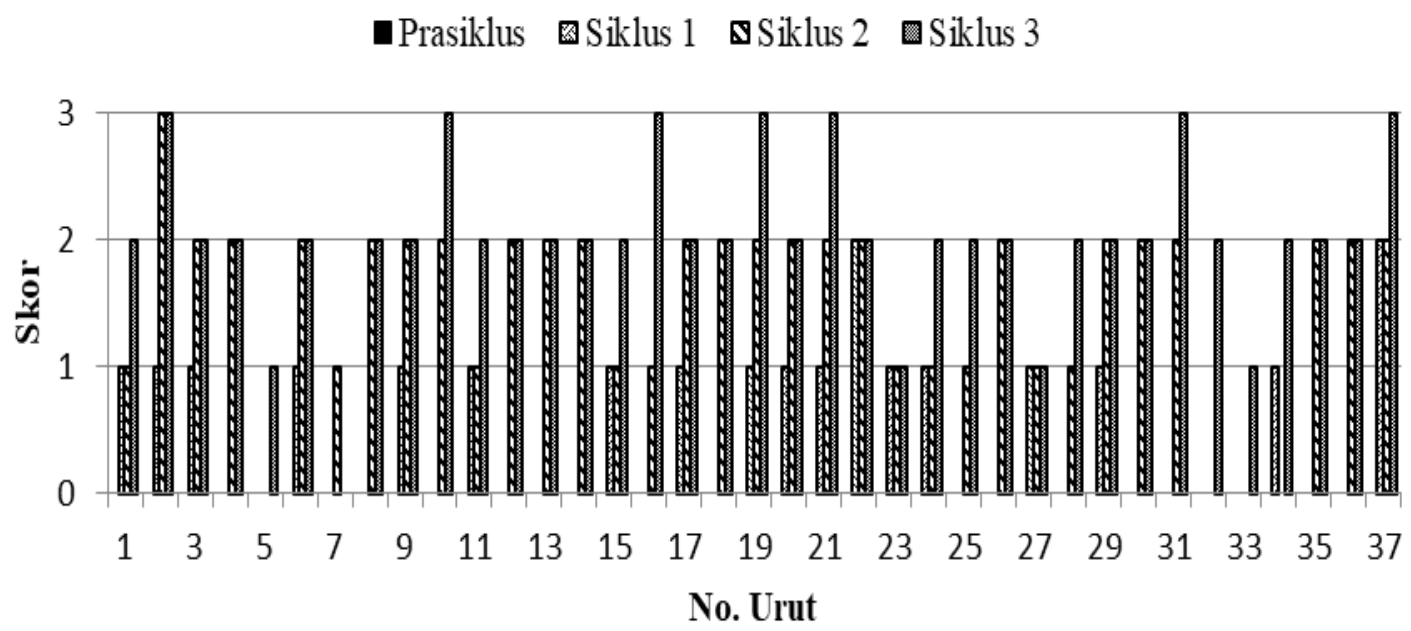

Gambar 2. Skor Aspek Evidence Tiap Siklus

Gambar 2 menunjukkan skor siswa pada aspek evidence. Siswa dengan nomor 19 dan 21 mengalami peningkatan skor secara kontinu dari prasiklus hingga siklus III, sedangkan siswa dengan nomor 10, 16, 25, 28, dan 31 menunjukkan peningkatan secara kontinu dari siklus I hingga siklus III. Peningkatan skor tersebut terjadi karena para siswa mampu berperan aktif berdiskusi untuk mencari informasi, data atau fakta baik itu di internet, buku maupun berdasarkan pengalaman mereka yang bisa dijadikan bukti (evidence) atas argumentasi yang disampaikan. Hal ini sesuai dengan pendapat Kultuca et al. (2014) bahwa salah satu prosedur kegiatan pembelajaran untuk meningkatkan keterampilan argumentasi adalah adanya keterlibatan peserta didik dalam mengumpulkan data atau informasi dan menyampaikan argumentasi. 
Siswa nomor 23 dan 27 mengalami peningkatan dari prasiklus ke siklus I dan skornya tetap hingga penelitian berakhir pada siklus III. Hal ini terjadi karena kedua siswa tersebut dari siklus I hingga siklus III menyampaikan evidence dalam kategori rendah. Penurunan skor terjadi pada siswa nomor 34 pada siklus II dan siswa nomor 7 pada siklus III karena siswa tersebut tidak hadir dalam kegiatan pembelajaran. Siswa dengan nomor 5, 32, dan 33 mulai mengalami peningkatan dari siklus II ke siklus III. Hal ini terjadi karena dari prasiklus hingga siklus II siswa yang bersangkutan masih kesulitan menemukan informasi, bukti atau fakta yang dapat digunakan dalam menyampaikan argumentasi. Analisa aspek evidence dalam argumentasi yang disampaikan oleh siswa dapat dilihat pada tabel 2.

Tabel 2. Contoh analisa aspek Evidence dalam Argumentasi

\begin{tabular}{|c|c|}
\hline \multirow{2}{*}{ 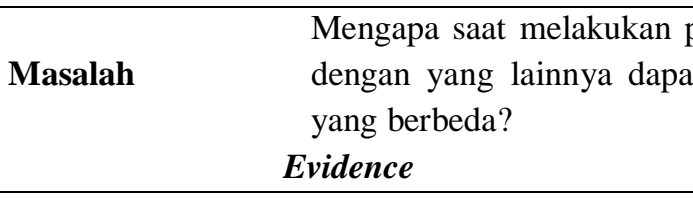 } & $\begin{array}{l}\text { n denyut nadi antara orang yang satu } \\
\text { kkan hasil yang sama dan ada pula }\end{array}$ \\
\hline & Keterangan \\
\hline $\begin{array}{l}\text { 2. Setelah } 1 \text { menit dicek denyut nadi saya } \\
\text { berbeda dengan teman saya, saya } 50 \mathrm{kali} / \text { menit } \\
\text { sedangkan teman saya } 85 \mathrm{kali} / \text { menit. }\end{array}$ & $\begin{array}{l}\text { Evidence yang disampaikan termasuk } \\
\text { dalam kaetgori tinggi karena data } \\
\text { yang digunakan dapat mendukung } \\
\text { claim. }\end{array}$ \\
\hline $\begin{array}{l}\text { 29. Saya sudah mengecek detak nadi saya } \\
\text { selama } 1 \text { menit berdetak } 72 \text { kali per menit. }\end{array}$ & $\begin{array}{l}\text { Evidence yang disampaikan termasuk } \\
\text { dalam kaetgori sedang karena bukti } \\
\text { yang disampaikan berdasarkan hal } \\
\text { yang pernah dialami oleh siswa } \\
\text { tersebut. }\end{array}$ \\
\hline \multirow[t]{2}{*}{ Masalah } & In mencegah gangguan atau penyakit \\
\hline & Keterangan \\
\hline $\begin{array}{l}\text { 27. Seseorang yang melakukan usaha pola hidup } \\
\text { sehat dengan cara teratur, istirahat yang cukup } \\
\text { biasanya seseorang itu terlihat masih segar bugar } \\
\text { walaupun umurnya lebih dari } 45 \text { tahun. }\end{array}$ & $\begin{array}{l}\text { Evidence yang disampaikan termasuk } \\
\text { dalam kaetgori rendah karena bukti } \\
\text { yang disampaikan hanya berdasarkan } \\
\text { fakta yang dilihat siswa tersebut. }\end{array}$ \\
\hline
\end{tabular}

Data pada gambar 2 menunjukkan bahwa siswa nomor 2 memiliki skor tertinggi aspek evidence pada siklus II dan siswa nomor 2, 10, 16, 19, 21, 31, dan 37 memiliki skor tertinggi aspek evidence pada siklus III. Bukti (evidence) yang disampaikan oleh siswa nomor 2 (Tabel 2) adalah evidence yang termasuk dalam kategori tinggi, yaitu berisi data yang mendukung claim. Hal ini sesuai dengan pernyataan Berland \& McNeill (2010) dan Roshayanti \& Rustaman (2013) bahwa sebuah bukti (evidence) berupa fenomena/data/fakta yang dapat membuktikan atau mendukung adanya sebuah 
pendapat (Claim). Sedangkan, evidence dalam argumentasi yang disampaikan oleh siswa nomor 29 termasuk dalam kategori sedang dan evidence dalam argumentasi yang disampaikan oleh siswa nomor 27 termasuk dalam kategori rendah. Aspek argumentasi lisan yang ketiga yaitu reasoning. Skor reasoning siswa mengalami perubahan pada setiap siswa (Gambar 3).

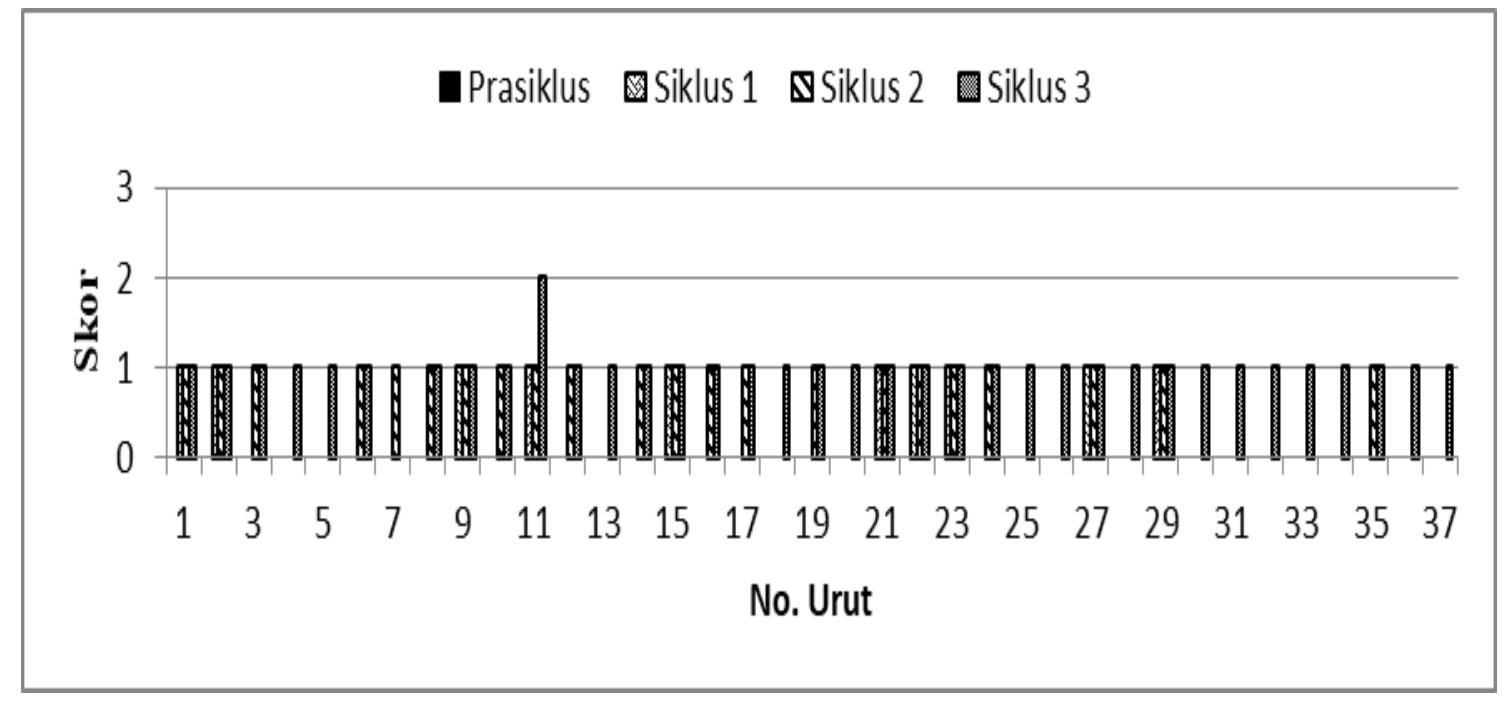

Gambar 3. Skor Aspek Reasoning Tiap Siklus

Berdasarkan gambar 3 terlihat bahwa skor reasoning siswa beragam. Siswa nomor 1, 2, 9, 15, 21, 22, 23, 27, dan 29 mengalami peningkatan skor dari prasiklus ke siklus I dan tidak terjadi perubahan pada siklus II maupuan siklus III. Siswa nomor 11 mengalami peningkatan dari prasiklus ke siklus I dan dari siklus II ke siklus III tetapi dari siklus I ke siklus II skornya tetap. Siswa nomor 4, 5, 13, 18, 20, 25, 26, 28, 30, 31, 32, 33, 34, 36, dan 37 mulai mengalami peningkatan skor dari siklus II ke siklus III, sedangkan siswa nomor 3, 6, 8, 10,12, 14, 16, 17, 19, 24, dan 35 mulai mengalami peningkatan dari siklus I ke siklus II tetapi skor tetap pada siklus III. Siswa dengan nomor urut 7 mengalami peningkatan dari siklus I ke siklus II dan mengalami penurunan pada siklus III karena siswa tersebut tidak hadir dalam kegiatan pembelajaran pada siklus III.

Hasil analisis aspek reasoning dalam argumentasi yang disampaikan oleh siswa dapat dilihat pada tabel 3. 
Tabel 3. Contoh analisa aspek Reasoning dalam Argumentasi

\begin{tabular}{|c|c|}
\hline $\begin{array}{ll}\text { Masalah } & \text { Bagaiamana cara untuk meng } \\
& \text { pada sistem peredaran darah m } \\
& \text { Reasoning }\end{array}$ & $\begin{array}{c}\text { mencegah gangguan atau penyakit } \\
\text { Keterangan }\end{array}$ \\
\hline $\begin{array}{l}\text { 11. Menghisap rokok secara berlebihan dapat } \\
\text { menyebabkan penyakit yang sangat mematikan, } \\
\text { yaitu penyakit kanker, jantung, paru-paru. Dan } \\
\text { merokok juga menyebabkan pecahnya pembuluh } \\
\text { darah hingga menyebabkan rusaknya peredaran } \\
\text { darah manusia }\end{array}$ & $\begin{array}{l}\text { Reasoning yang disampaikan } \\
\text { termasuk dalam kaetgori sedang } \\
\text { karenareasoning yang disampaikan } \\
\text { berupa sebuah pembenaran bahwa } \\
\text { informasi dapat dijadikan sebagai } \\
\text { bukti untuk pendapat yang } \\
\text { disampaikan. }\end{array}$ \\
\hline $\begin{array}{l}\text { 27. Seseorang yang hidup dengan pola hidup yang } \\
\text { sehat pasti akan terjaga kesehatannya dan } \\
\text { terhindar dari penyakit yang berbahaya sehingga } \\
\text { peredaran darah akan lancar walaupun usia tua } \\
\text { (Reasoning). }\end{array}$ & $\begin{array}{l}\text { Reasoning yang disampaikan } \\
\text { termasuk dalam kaetgori rendah } \\
\text { karena berisi alasan yang } \\
\text { menyatakan suatu hal yang } \\
\text { menghubungkan claim dengan } \\
\text { evidence. }\end{array}$ \\
\hline
\end{tabular}

Berdasarkan gambar 3, siswa dengan nomor 11 memiliki skor tertinggi aspek reasoning pada siklus III, namun alasan (Reasoning) yang disampaikan siswa nomor 11 termasuk dalam kategori sedang yaitu berupa pembenaran bahwa informasi dapat dijadikan sebagai bukti untuk pendapat (claim) yang disampaikan. Menurut Evagorou \& Osborne (2013), reasoning merupakan sebuah alasan yang digunakan untuk membenarkan hubungan antara data dan kesimpulan. Berdasarkan pendapat Evagorou \& Osborne (2013), reasoning dengan kategori rendah terlihat pada siswa nomor 27.

Hasil analisis terhadap keterampilan argumentasi lisan siswa menunjukkan perubahan setiap siklusnya. Berikut merupakan perbandingan keterampilan argumentasi lisan siswa pada setiap siklus.

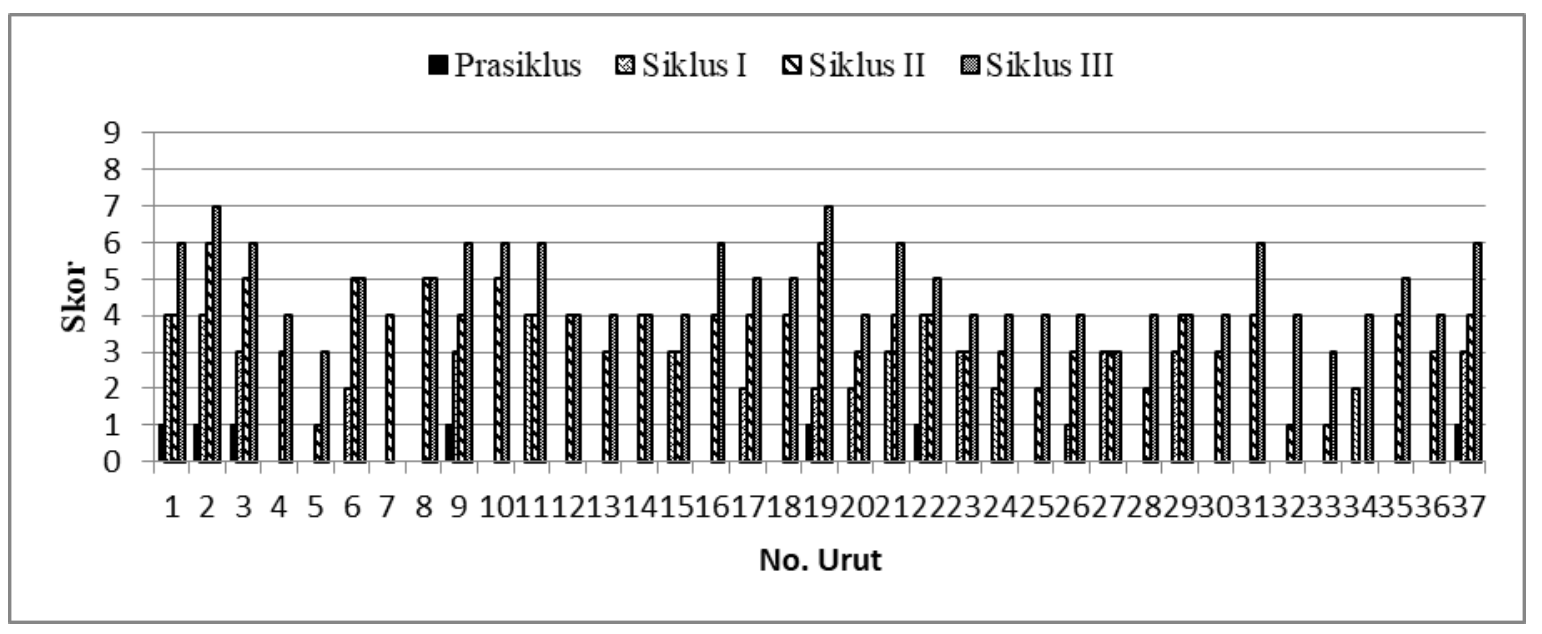

Gambar 4. Skor Keterampilan Argumentasi Lisan Siswa Tiap Siklus 
Berdasarkan gambar 4 terlihat bahwa skor keterampilan argumentasi lisan siswa mengalami perubahan dari prasiklus hingga siklus III. Siswa nomor 2, 3, 9, 17, 19, 20, 21, 24, 26, 29, dan 37 mengalami peningkatan skor keterampilan argumentasi lisan secara kontinu, sedangkan siswa dengan nomor 27 mengalami peningkatan dari prasiklus ke siklus I tetapi tidak mengalami perubahan dari siklus I ke siklus II maupun dari siklus II ke siklus III. Hal ini terjadi karena siswa nomor urut 27 masih kesulitan dalam menyampaikan argumentasi sehingga tidak mengalami peningkatan skor pada ketiga aspek (claim, evidence, dan reasoning) mulai dari siklus I ke siklus II dan dari siklus II ke siklus III. Siswa nomor 34 mengalami peningkatan dari prasiklus ke siklus I tetapi mengalami penurunan pada siklus II dan kembali mengalami peningkatan pada siklus III, sedangkan siswa dengan nomor urut 7 mengalami peningkatan dari siklus I ke siklus II dan mengalami penurunan dari siklus II ke siklus III. Siswa nomor urut 34 dan 7 mengalami penurunan skor karena tidak hadir dalam kegiatan pembelajaran.

Berdasarkan hasil observasi pada prasiklus diketahui bahwa keterampilan argumentasi lisan siswa berada pada level yang paling rendah, yaitu siswa hanya dapat menyampaikan aspek claim. Hal ini sesuai dengan Chin \& Osborne (2010) yang menyatakan bahwa suatu argumentasi pada level 1, apabila argumentasi hanya berisi satu claim sederhana, dan argumentasi berada pada level 2, apabila argumentasi berisi claim dengan data pendukung. Skor keterampilan argumentasi lisan siswa setelah dilakukan penelitian siklus I hingga siklus III menunjukkan adanya peningkatan, yaitu siswa dapat menyampaikan argumentasinya secara lisan yang terdiri dari claim disertai dengan bukti (evidence) dan alasan (reasoning) yang mendukung pernyataannya, sehingga argumentasi pada prasiklus yang tergolong kategori rendah mengalami peningkatan pada kategori sedang setelah dilakukan penerapan pembelajaran Problem Based Learning.

Peningkatan skor argumentasi lisan siswa dapat terjadi karena dalam kegiatan pembelajaran guru menyajikan sebuah masalah yang berkaitan dengan kehidupan sehari-hari sehingga mampu menggali rasa keingintahuan siswa. Hal ini sesuai dengan pernyataan Maggi \& Claire dalam Wulandari \& Surjono (2013) bahwa penyajian suatu masalah bisa menarik minat siswa sehingga proses pembelajaran tidak monoton. Kegiatan penyajian masalah ini dilaksanakan pada sintaks problem encounter/meeting the problem dalam penerapan pembelajaran Problem Based Learning. Selain itu, 
berdasarkan hasil wawancara dengan siswa diketahui bahwa dengan memberikan kesempatan kepada siswa untuk mencari data atau informasi pada pelaksanaan sintaks discovery and reporting serta menyampaikan argumentasinya pada pelaksanaan sintaks solution presentation and reflection dalam menerapkan pembelajaran Problem Based Learning dapat memberikan pemahaman siswa tentang materi pelajaran. Hal ini sejalan dengan pernyataan Cross et al. (2008) bahwa argumentasi dapat membantu menambah pemahaman siswa mengenai konsep serta dapat memperluas pengetahuannya melalui cara memperoleh ide-ide yang baru.

\section{SIMPULAN}

Berdasarkan hasil penelitian yang dilaksanakan selama tiga siklus disimpulkan bahwa ada peningkatan keterampilan argumentasi lisan siswa melalui Problem Based Learning di kelas XI MIPA pada pembelajaran biologi. Keterampilan argumentasi lisan siswa mengalami peningkatan dari level rendah ke level sedang dengan rata-rata skor keterampilan argumentasi lisan siswa pada prasiklus 0,19, siklus I 1,43, dan siklus II 3,49 , serta rata-rata skor 5 pada siklus III.

\section{UCAPAN TERIMA KASIH}

Teriring syukur kepada Allah SWT saya mengucapkan terimakasih kepada semua pihak yang telah terlibat dalam penelitian ini.

\section{DAFTAR PUSTAKA}

Berland, L. K., \& McNeill, K. L. (2010). A learning Progression for Scientific Argumentation: Understanding Student Work and Designing Supportive Instructional Contexts. Science Education, 765-793.

Chin, C., \& Osborne, J. (2010). Supporting Argumentation Thriugh Students' Questions: Case Studies in Science Classroom. Learning Science, 19 (2): 230284.

Coghlan, D., \& Brannick, T. (2010). Doing Action Research in Your Own Organization. London: Sage.

Cross, D., Taasoobshirazi, G., Hendricks, S., \& Hickey, D. T. (2008). Argumentation: A strategy for improving achievement and revealing scientific identities. International Journal of Science Education, 30 (6): 837-861.

Evagorou, M., \& Osborne, J. (2013). Exploring Young Students' Collaborative Argumentation Within a Socioentific Issue. Journal of research in science teaching, 50 (2): 209-237. 
Kultuca, A. Y., Cetin, P. S., \& Dogan, N. (2014). Effect of Content Knowledge on Scientific Argumentation Quality: Cloning Context. Journal of Science and Mathematics Education, 8 (1): 1-30.

McNeill, K. L., \& Krajcik, J. (2008). Scientific Explanations: Caharacterizing and Evaluating the Effects of teachers' Instructional Practices on Student Learning. Journal of Research in science Teaching, 45 (1): 53-78.

McNeill, K. L., \& Krajcik, J. (2009). Synergy Between Teacher Practices and Curricular Scaffolds to Support Students in Using Domain-Specific and Domain-General Knowledge in Writing Arguments to Explain Phenomena. The Journal of The Learning Sciences, 18; 416-460.

Roshayanti, F., \& Rustaman, N. Y. (2013). Pengembangan Asesmen Argumentatif Untuk Meningkatkan Pola Wacana Argumentasi Mahasiswa pada Konsep Fisiologi Manusia. Bioma, 2 (1): 85-100.

Syaifudin, A., \& Pratama, H. (2013). Pengembangan Buku Teks Menulis Argumentasi Berdasarkan Pola Penalaran Argumentatif. Jurnal Penelitian Pendidikan, 30 (1): $1-10$.

Tan, O. S. (2007). Problem-Based Learning Pedagogies: Psychological Processes and Enhancement of Intellogences. Educ Res Policy Prac, DOI 10.1007/s10671007-9014-1, 6: 101-114.

Wulandari, B., \& Surjono, H. D. (2013). Pengaruh Problem Based Learning Terhadap Hasil Belajar Ditinjau Dari Motivasi Belajar PLC Di SMK. Jurnal Pendidikan Vokasi, 3 (2): 178-191. 